\title{
How Women Family Business Leaders Are Thriving in Morocco
}

\author{
Dora Jurd de Girancourt (ESCA École de Management) \\ Thami Ghorfi (ESCA Ecole de Management)
}

KEYWORDS: Family Business, Women, female leadership.

For generations, grandmothers, mothers, daughters and aunts have played informal, behind-the-scenes but important roles in family businesses worldwide. They have provided critical emotional support to the men involved in the business. While researchers have studied women's roles in western countries (Cole, 1997; Harveston, Davis and Lyden, 1997; Vera and Dean, 2005; Jimenez, 2009); few have examined their roles in Morocco or Africa.

Our recent study was the first to analyze the real place of female family members working in Moroccan family businesses. We surveyed about 100 Moroccan family business owners (both male and female), held in-depth discussions with 30 women business leaders, and analyzed others' research on women and business. Our report, "Femmes au coeur des entreprises familiales" ("Women at the Heart of Family Businesses") was published in March of 2021 by La Croisée des Chemins. Our insights can be useful for family businesses and women leaders around the world.

\section{Why Morocco?}

According to several official sources in Morocco (HCP Haut Commissariat au Plan and the Moroccan barometer BDO-ANPME), family businesses account for approximately $90 \%$ of the national economy, yet the rate of female participation in the workforce barely reaches $21 \%(\mathrm{HCP})$. We sought to find out: What is the place of female family members working within local family businesses? How are they perceived by the firm, the family and society? What are their challenges and their success drivers?

To get some answers, we conducted a study at ESCA École de Management, based in Casablanca, about female family members' status in Moroccan family businesses. Through our research we saw that a new generation of highly educated, fully trained female

relatives are taking the reins of local family businesses. Some succeed in breaking the glass ceiling to reach top leadership positions and inspire other women who still hesitate to dig into the workforce or to work in a family business.

At the same time, Moroccans are becoming more in favor of women participating in the workforce, especially in family businesses. Our study included an online survey to gather opinions on the place of female family members in family businesses. Analyzing responses from about 100 female and male professionals, working in family and non-family businesses in diverse sectors across the country, told us this:

- Mentalities still must evolve towards a more favorable opinion on women participation in the workforce.

- Female family members bring an unquestionably positive contribution to most family businesses.

- Elevating female family members to managerial and leadership positions in the family business will only improve the succession process for the next generation, as women are particularly good at managing conflicts.

- However, female family members still need to prove their legitimacy in the family business.

\section{Major Drivers of Success}

To explore this topic more deeply, we carried out a thorough literature review and a qualitative analysis based on 30 interviews with female family members working in family businesses in diverse sectors and locations across the country. We identified their major success drivers and analyzed how well the family business setting nurtured them professionally. Despite many obstacles they had to overcome, we found out that six main factors contribute to their success. 
1. Being mentored by other inspiring women of the family.

Most female leaders have been mentored from the youngest age by strong women of their family. Most often, these mothers, grandmothers or aunts from the former generation -- even if they hadn't worked themselves formally in the family business -- have encouraged their daughters to take managerial positions and make their voice heard in the industry. They know the company rules, have witnessed its history and its ups and downs, learned how to manage emotions, and usually act as guardians of the family's values and history. They also inspire and guide younger women in their quest for power and leadership.

\section{Being supported by the men of the family.}

The men of their family - father, brothers, uncles, or cousins - can support women in their professional rise to power. In Morocco, the men of the family help women to get a foot on the ladder. The father, especially when he is the founder of the company, can be the most significant influence on his daughter. His advice is vital to support the daughter's first major decisions. He usually plays a considerable role in ensuring his daughters receive the same education as his sons. After a few years, women like to make their own decisions and make their own choices, but the father remains a guide and a mentor who is often consulted.

\section{Actively participating in the business from the youngest age.}

Female leaders in family businesses were more and more prepared to take over. They have usually studied the family business sector enough to be fully knowledgeable when they assume leadership. Since their birth, they have also been immersed in the family culture and have adopted the family's values and codes. They have used these values to climb the ladder and want to hand them over to their children.

\section{Working with head and heart.}

These women feel both a duty and a deep emotional attachment to the family business (Sharma and Irving 2005). They are aware of the weight of legacy and do not want to disappoint family members, external partners or any other stakeholders. They often consider their work as a real mission, far beyond the work itself. When they have committed to the family business, they seldom regret it. Most acknowledge that they have a challenging but particularly meaningful job.

\section{Professionalizing the "chief emotional officer" role.}

These women successfully manage their intertwined family and professional lives. According to the HCP, $95 \%$ of Moroccan women, from all socio-economic backgrounds, bear the majority of domestic chores, and women who lead family businesses are no exception. But this double hat gives them a role of "chief emotional officer" to play both in the company and the family: they become the ones who debug conflicts, analyze the emotions, and moderate personal egos.

\section{Using the family atmosphere as a competitive advantage to thrive professionally.}

These women admit that they have had to prove their legitimacy twice as much as men and overcome many social barriers from their family and social environment. But overall, they acknowledge that the family business has been a supportive environment bringing them confidence, trust, support, accessible mentorship, and a family atmosphere where they felt relaxed and confident enough to succeed. This confirms what some researchers have already discovered about how female values and family business values have become equivalent. (Hollander \& Bukowitz, 1990; Amore et al. 2014; Samara et al. 2019).

To wrap up, this research emphasizes three main learnings. First, these successful women in a patriarchal country like Morocco have succeeded in leveraging some social barriers to their competitive advantages. For example, they turned the heavy tutelar figure of the father into a guide or mentor, and they used their heavily intertwined personal and professional lives to act as emotional officers in the business.

Second, they received a modern and egalitarian education from their family, who considered them legitimate successors since the beginning. Their professional role in the family business was formalized, and they were not considered a "second-tier" successor.

Finally, they thrived in the family business environment thanks to a climate of trust and shared values. Several researchers have already analyzed that family businesses could be catalysts for women's employment. 
We can go even further -- and say that our research shows that family businesses can be catalysts for women to reach top leadership positions.

In terms of practical implications for male and female family business entrepreneurs operating in the region, this research pointed out that female family members are gaining self-confidence, a key resource to succeed both internally and externally. These pioneers pave the way and become genuine role models for other Moroccan women. They demonstrate that, with selfconfidence and determination, one can define her own leadership style and be successful.

\section{Learn more}

"Femmes au coeur des entreprises familiales," by Thami Ghorfi and Dora Jurd de Girancourt, Éditions La Croisée des Chemins, March 2021, Casablanca, Morocco. This study was conducted within the research Chair of Family Business in Morocco at ESCA École de Management. 